\title{
Faith and Health: Past and Present of Relations between Faith Communities and the World Health Organization
}

\author{
The Rev. Canon Ted Karpf ${ }^{a}$ \\ ${ }^{a}$ Th.M. former Partnerships Officer, WHO headquarters - 2003-2010, and retired priest living in rural New Mexico
}

\begin{abstract}
Relationships between faith communities and international multi-lateral organizations can be complicated. While there is potential for synergy between the two, different values often characterize the approach of each. The history of these relationships is illustrative. This review describes collaboration between the World Health Organization (WHO) and faith-based organizations (FBOs) in the implementation of primary health care, the role of spirituality in health, community responses to the HIV pandemic, and definitions of Quality of Life containing spiritual dimensions. However, important gaps persist in the appreciation and measurement of the contribution of faith communities to health assets on the part of governments and the WHO. FBOs can still draw from the nine points developed in the 1960s as a timetested viable agenda for current and future operations.
\end{abstract}

\section{Introduction}

It seems to be time for the Christian community of health care providers and the international multi-lateral organizations to work together, AGAIN! We've been here before. This "revolutionary" movement of service provision or resource sharing among governments, NGOs, and faith-based organizations is not new but has quite a history of periodic relating and long-term neglect.

Since the Middle Ages, the establishment and maintenance of institutions to care for the sick has been the priority for the Western Christian church. In his book, Sent to Heal!, Christopher Grundmann describes that in the $16^{\text {th }}$ and $17^{\text {th }}$ centuries the Jesuits and Franciscans sent missionaries to the New Worlds: Africa, Asia, and the Americas, where they practiced medicine, surgery, and pharmacy. ${ }^{1}$ Christian polities of other colonizing nations soon followed suit. English missionary, Samuel Marsden, founder of the Church Missionary Society's mission to the Maori in New Zealand in 1819, used the term "medical missionary" in a letter where he requested physicians to assist him in mission. ${ }^{1}$ The term "medical missions" occurs formally for the first time in the official records of the Edinburgh Medical Missionary Society in 1842.

\section{The Ecumenical Movement and the Rise of Christian Health Services}

The Christian approach to health improvement as mission work was born out of the belief that there is something peculiarly Christian about the business of health and healing. Jesus healed. The beneficiaries of his ministry were not primarily the rich or the strong, although these were by no means excluded. They were the poor, the sick, the stigmatized, and the disabled. When missionaries observed the needs for both improved hygiene and basic medical services and 
responded to both, the interrelationship between mission, public health, and health care delivery began.

In the 1960s, the ecumenical movement and widespread Christian engagement with missions and health care services came together to give rise to the creation of the Christian Medical Commission (CMC). CMC became a forum through which theologians, Christian missionaries, and health care service providers explored the meaning of their work in the context of the broad social justice movements emerging around the globe. Diane Smith brilliantly compiled the history of CMC, documenting the seminal Tubingen consultations and the initial World Council of Churches/World Health Organization collaboration. The reader is encouraged to consult Smith's history, which was published in the last double issues of the World Council of Church's magazine Contact in the summer of $1998 .^{2}$

Highlights include discussions of the following: the role of Christian health care providers, the relationship of role and mission, the process by which religious institutions came to work with other entities to extend their influence, and the broad range of health services that religious institutions had come to provide in the countries where they had missions. Smith's history is notable for its honesty. Most Christian medical missions tended to make the same mistakes that other aid groups made in their inability to fit themselves to local circumstances, to nimbly scale up or down, and to assume their cultural mindset matched the local reality.

A great contribution of this seminal latetwentieth century work was the recognition that collaboration across denominations or sectors of influence (health, government, faith-based organizations) was usually more effective than competing for scarce resources or than operating in isolation. As both the Christian Medical Commission and the World Council of Churches became more articulate about their distinctive contribution to the delivery of quality preventive and curative health services across the globe and as more former missionaries entered leadership roles in health agencies (such as the U.S. Centers for Disease Control and the World Health Organization), it became possible for religious and secular agencies to dialogue about common problems and to develop joint strategies to solve them.

\section{Christian Medical Commission and Primary Health Care}

As Smith recounts,

On 22 March 1974, Dr. Halfdan Mahler, Director-General of the World Health Organization (WHO), called together senior staff for a joint meeting with all five senior staff of the CMC. As a result of this meeting, a joint committee was set up to explore the possibilities of collaboration and cooperation in "matters of mutual concerns." In spite of the disparity in size, the relationship between the two organizations turned out to be exceptionally fruitful. The most significant result of the CMC/WHO relationship was the formulation by WHO, in 1975, of the principles of primary health care (PHC). This marked a radical shift in WHO priorities, with massive implications for health care systems everywhere.

At WHO's 1976 Assembly, Dr. Mahler called for the use of primary health methodology to make health services available to all by the year 2000 and offered the facilities of WHO to analyze the problems of each country, so as to enable development of health policies and targets which would help national governments achieve this goal. The proposal was adopted and became the subject of the international conference on Primary Health Care held in Alma Ata in the USSR (today Almaty, Kazakhstan) in September 1978. $\mathrm{CMC}$ was closely involved in planning and many presenting came from members of the CMC family. This moment was a zenith for the work of CMC and its constituents. 
In this process, WHO was trying to develop a simple and easily understandable methodology which could be replicated and which carried a stamp of approval that might make it acceptable to governments. However, making PHC universal through governmental programs created its own problems. The original vision of PHC had been a force for liberation and empowerment through the promotion of health care. Once it had been watered down to methodology acceptable to governments, it could no longer address key issues such as corruption and oppressive systems. Governments interpreted placing "maximum reliance on available community resources" as a means of saving costs. Meanwhile, CMC and other NGOs made every effort to promote the original concept emphasizing the need for community involvement and the need to draw in other sectors, such as agriculture and education. However, gradually PHC came to be a topdown government approach, rather than bottom-up people's initiative. $^{2}$

\section{A Parting of the Ways}

Within a year, WHO and WCC-CMC parted company, heading in different directions. Dr. Charles Elliott, a priest and economist, addressed the CMC Annual Meeting with his talk, "Is Primary Health Care the New Priority? Yes, but ...." Meanwhile, James McGilvray wrote in Contact in the same year that PHC was all but dead and decried the top-down philosophy. While there was no formal disagreement per se in terms of relations between WHO and WCC, there was clearly a cooling of relations. Elliott's words seem to sum up the dilemma and opportunity.

We have a lot in common with WHO, but our ultimate aims are not the same. For a Christian organization to ignore the importance of the spiritual dimension of health is for it to ignore the really crucial input it has to make to the debate about the nature of healing. Health is more than medicine. It is to do with the way you live and way you die, the quality of life and the quality of death. The ultimate answer to disease lies in a way of life - a life of surrender and obedience that leads to wholeness. $^{2}$

Where WCC represented the ecumenical movement with the ambition and dream of Christian Unity, the WHO serves government as the world's public health agency. The tensions about government and the traditional secular/sacred debate, not to mention the Christian view of the world versus many other religions or cultures, were real and often intractable. Collaborating in an environment in which the dream of primary health care was subverted to a government program was, in itself, enough to quell enthusiasm if not end most collaborations and meetings of concern. But like many governmental and faithbased health care service provider relationships, they never expanded and deepened to meet the hopes and expectations of the various parties, and they never went away completely enough to ignore. They simply co-existed while change and development moved forward or backward depending on which country and the state of government relations at any specific time.

\section{HIV/AIDS}

The gathering storm of a worldwide HIV/AIDS pandemic through the 1980s and 1990s created both a crisis and an opportunity for those interested in the intersection between Christianity and health mission work. Without going into detail, it is safe to say that there was great division in Christian churches about HIV/AIDS. Debates raged about sin and sickness, justice and decency, sexual activity and God's judgment, the theology of disease, and the role of guilt. Such debates broke out in all quarters within and without Christianity and through organized religion as a whole. Many communities of faith stepped up to provide basic support services to people living with HIV/AIDS, and some faith-based health service providers re- 
ported systems at near breaking points in the face of such a health threat. Larger polities and denominations also began to engage with AIDS mission work led often by individuals dedicated to meeting human need. In the mid-90s, as the WCC was preparing for its World Assembly at Harare, a long issue of CMC Contact was devoted to HIV/AIDS. WCC also commissioned a report for Harare that was widely researched. It reported on what Christian communities were doing around the world to support those living with HIV/AIDS. This author was one of those interviewed for that report in a full day seminar at the US National Council of Churches in New York. The report cited extensive HIV/AIDS ministries supported by larger polities DIFAEM (German Institute for Medical Mission and founding member of the CMC), Lutheran World Service, and the Anglican Communion through their respective member churches or dioceses, United Methodist Board of Global Ministry AIDS Program, Christian Aid in the UK, Norwegian Churches, and agencies like AUS Aid. In more challenging and developing world societies, repeated attempts by the WCC and by national ecumenical and local church councils were slowly succeeding in creating local, indigenous, and more generous responses to HIV/AIDS.

But the long separation between theology and health care at the congregational level left the clergy unknowing about matters relating to health care, basic biology, and the process of disease and, thus, unable to speak in coherent meaningful ways to either their congregations or those infected with HIV. Thanks to the treatment literacy growing out of AIDS activism, those infected often had a better understanding of their disease than their families, community, or the congregation, and, too often, their personal stories and witness outside the community invited others to take action in their behalf.

\section{Quality of Life, and Spirituality, Reli- gious and Personal Beliefs}

During that same period, the littlepublicized Department of Mental Health of the WHO published a report from the WHO Consul- tation on Quality of Life and Spirituality, Religiousness and Personal Beliefs (SRPB) held June 22-24, 1998 in Geneva. The objectives for the meeting were as follows:

- To explore the meaning of SRPB as it relates to the quality of life and health.

- To define, as clearly as possible, potential facets of SRPB.

- To review existing facets and propose additional facets to the WHO QOL.

- To suggest facets which may apply to some religious groups and not others (in the same way that national items have been included in the WHO QOL-100).

- To begin to draft some items.

- To produce a broad protocol for followup work at country level to produce a module. $^{3}$

The WHOQOL is an instrument developed for measuring quality of life. From the manual, "These instruments have several uses, including use in medical practice, research, audit, health services and outcomes evaluation, and in policy making". ${ }^{3}$ The document goes on to say,

Until recently the health professions have largely followed a medical model, which seeks to treat patients by focusing on medicines and surgery, and gives less importance to beliefs and faith (in healing, in the physician and in the doctorpatient-relationship). This reductionism or mechanistic view of patients as being only a material body is no longer satisfactory. Patients and physicians have begun to realize the value of elements such as faith, hope and compassion in the healing process. The value of such 'spiritual' elements in health and quality of life have led to research in this field in an attempt to move towards a more holistic view of health that includes a nonmaterial dimension emphasizing the connectedness of mind and body. Research in such areas as psychoneuroimmunol- 
ogy, for example, has shown the linkage between how we feel and how our physical health, in this case the immune system, can be affected. Examples of mind body relations are the essence of psychosomatic medicine. ${ }^{3}$

While the report was published and circulated, it bears the standard WHO disclaimer," This document is not a formal publication of the World Health Organization and all rights are reserved by the Organization., "3 In order to provide an exhaustive understanding of the great traditions, the document included background essays by Hindu, Buddhist, Muslim, Christian, and Jewish scholars and health professionals to ensure that the spiritual traditions and ethics of each tradition was included and explored. This was a first for WHO exploring the values and role of faith from the health perspective.

Another historical note is found in the introduction on page 4 stating:

Since the 1983 World Health assembly, the issue of dealing with the "nonmaterial' or 'spiritual' dimension of health has been discussed extensively. A resolution of the $101^{\text {st }}$ session of the Executive Board in 1998 requests the Director General to consider an amendment to the constitution of the WHO defining health as "a dynamic state of complete physical, mental, spiritual and social well-being and not merely the absence of disease or infirmity."

This resolution was considered at the fiftysecond World Health Assembly in May 1999 and was tabled without a concluding vote. Thus, this issue remains on the table of the Assembly to be reconsidered at any time.

\section{HIV and QOL}

Finally, regarding HIV/AIDS, the same report included a summary of a WHO Global Program on HIV/AIDS Consultation was held in the previous year, 1997, which attempted to describe facets to be added to the SRPB domain. These were generated for a module created for people with HIV/AIDS in order to provide a starting point for a more general SRPB module. A review of the seven areas focused upon in this meeting were as follows: Meaning of Life, Forgiveness, Beliefs, Spiritual connectedness, Personal spiritual experience, Feeling of harmony with past, present, and future, Death and dying. ${ }^{3}$

These same thematic areas remained a focus throughout the worldwide HIV/AIDS pandemic and helped form a foundation for the WHO HIV/AIDS program of outreach to faith communities and a touchstone for the HIV/AIDS program from 2004-2011.

With the advent of the " 3 by 5 " initiative, created in 2003 by the late WHO DirectorGeneral Dr. J.W. Lee, led by Dr. Jim Kim, and endorsed by the WHO Assembly in 2004, a target was set that three million HIV+ persons should be in treatment by the close of 2005 . That would be a virtual doubling of the number of persons in treatment in three years. It was a noble goal that was missed in 2005, but reached in 2006 ! For the first time in many years, though, the self-conscious attention of the WHO turned again to faith communities, which both operated health services and offered hope, help, and potential resistance in meeting this target. The lack of government response and enthusiasm in both prevention and treatment of HIV/AIDS made it evident that other allies were needed beyond the treatment communities of the infected and international NGO providers like Médecins Sans Frontières - MSF (Doctors without Borders), AIDS Action, Persons Living with HIV/AIDS, and other coalitions worldwide.

\section{Health Agencies Seek Faith-Based Partners Again}

At the same time, UNAIDS saw a remarkable opportunity in many countries to bring together grassroots coalitions and communities to support and expand upon the " 3 by 5 " initiative. Securing the leadership of Ms. Sally Smith, a nurse and former medical missionary in Nepal, UNAIDS undertook grassroots organizing work- 
ing alongside former candidate for holy orders and Danish gay rights activist, Mr. Calle Almedal. Smith, specifically, reached out to faith communities with a dynamism that became an instant hallmark of the UNAIDS program. The ongoing work of documentation and consultation became the style undertaken by Ms. Smith, but it was evident then that the AIDS effort needed faith communities to promote AIDS prevention and education, along with their ongoing work to create healthier communities and nations.

WHO, likewise, perceived the necessity of sending an envoy to communities outside of their usual national public health constituency to reach out to communities of people with HIV/AIDS as well as to faith-based organizations and faith communities and to business and trade unions. I was recruited among several activists for the program as a long-time AIDS advocate who was a missionary canon for HIV/AIDS in Southern Africa through the Anglican Communion and supported by USAID. I served in the US Public Health Service as the nation's first HIV/AIDS liaison specialist, recruited by Kim to be that envoy. I was directed to recruit faith communities and communities of the affected and infected to support and assist in garnering national and international support for the WHO HIV/AIDS Program of treatment expansion to meet the 2005 target. I joined the program in spring of 2004 and by January 2005 had built a small team to reach out to international partners: PLHIV organizations, HIV/AIDS NGOs, and faith communities, alike. However, there was a deep resistance on both sides of the equation, particularly about the role of faith communities, who were often cast as those who condemned people living with or affected by HIV/AIDS.

Since the 1980s, there had been no systematic data collected about faith communities and their religious health assets, particularly the scope of what they actually did. The relative failure of the world to reach "health for all" by 2000 created fallout and distrust, and as a result, there had been little substantive communication with the WCC or CMC for nearly a decade. There were also new players in the international health and development arena: Islamic Relief, Adventist Development and Relief (ADRA), Catholic Relief Services (CRS), American Jewish World Service (AJWS), CARITAS Internationalis, World Vision, Aga Khan Foundation, a number of Hindu-related health and hospital systems in India, BRAC in Bangladesh, Buddhist hospices in Thailand, Myanmar, and Cambodia along with a number of US-based super churches, all claiming to be doing AIDS/HIV work. Many of these organizations had developed relationships with the US government through domestic and international contracts and agreements.

To address the evidence gap and go beyond mere anecdotes and stories, in July 2005, WHO commissioned the Interfaith Health Program of Emory University Rollin's School of Public Health in collaboration with the University of Cape Town to study the actual "on the ground" shape of religious health services within several districts of Zambia and Lesotho. Along with this study, the European Union funded several studies on the same districts around internationally funded HIV/AIDS programs to determine their efficacy and efficiency and to document their relationships with the local, regional, and national government. The Global Fund also funded WHO to monitor several studies to determine how international funding was flowing to faith-based organizations and identify the relative percentage support given to faith-based organization in comparison to other communitybased NGOs. The project was known as the Italian Initiative. Meanwhile, WHO assisted WCC in reconvening faith community health service providers to discuss and plan for more effective HIV/AIDS services and to study Primary Health Care. WHO and UNAIDS also funded several denominational and faith community studies to "get a handle" on who was doing what with whom. For four years, a flurry of studies yielded startling and yet consistent information about what was going on in the field by faith communities and their sponsored health services. 


\section{Impact of Religious Health Assets}

In late 2006, the ARHAP Report, as it came to be called, Appreciating Assets: The Contribution of Religion to Universal Access in Africa - Mapping, Understanding, Translating and Engaging Religious Health Assets in Zambia and Lesotho In support of Universal Access to HIV/AIDS Treatment, Care and Prevention, was presented to $\mathrm{WHO}$ at an international press conference at Washington National Cathedral, Washington, DC, in February 2007, with active participation by UN agencies and faith communities with representatives from around the world. ${ }^{4}$

The findings of the "ARHAP Report" were both clear and tentative. It was evident that there was a long way to go to fully describe and understand what had been happening on the ground with the work of religious communities. That faith-based organizations were significant in health care delivery at the country level could no longer be questioned. WHO claimed that Religious Health Assets (RHAs), which were sponsored by faith communities, faith-based or faithinspired, organizations, could provide up to $40 \%$ of the health services in any given country. These RHAs were primarily dedicated to health care and were less concerned about the faith or faith traditions of their founding, but that they were "unafraid" to claim faith was not a matter of controversy. More specifically, the ARHAP Report also revealed a much more pragmatic response in a broader way to include traditional healers, sangomas, witch doctors, as part of the overall community health service system. It was a more nuanced, diverse, and wider-reaching landscape than WHO had expected.

The ARHAP Report had also demonstrated that there was also a problem with the actual tool used by WHO Health Mapping Program. While the WHO reported a minimal number of health services in the researched area, ARHAP investigators found literally hundreds of providers. Further investigation and conversations within the WHO leadership revealed that the Services Availability Mapping and Readiness Assessment (SAM) simply missed or overlooked longtime, well-established facilities operated by religious foundations or religious communities. The unique identifiers were skewed in such way as to overlook the "who or what" entity that provided the health service depending on the notion of whether or not they were a for-profit or nonprofit entity. In 2009, a consultation convened in partnership with the US-based Center for Interfaith Action on Global Poverty (CIFA), the World Council of Churches, and WHO; it was held to develop a consensus on how health mapping could be enhanced with the fine-tuning of the unique identifier. The WHO-CIFA Report contained in the archive of the Anglican Health Network Executive Summary reported it this way:

Based on WHO's tool and methodology for assessing and mapping health services availability and readiness (SAM), working groups discussed standard approaches to data collection, management, use, and dissemination for mapping data that represent the value added by FBOs in health services delivery, especially those religious health assets deemed to be intangible or at least difficult to quantify. Specific modifications to the Services Availability and Readiness Assessment ("SAM") core instrument were suggested, including the addition of a module to represent specific interests of FBOS (e.g., provision of free or concessional care, capacity for spiritual care providers and volunteer staff, and provision of psychosocial services, including bereavement services) ${ }^{5}$

\section{Back to Primary Healthcare}

In 2008, Building From Common Foundations: The World Health Organization and FaithBased Organizations in Primary Healthcare was published jointly by the WHO and Geneva Global Performance Philanthropy, a US-based global philanthropy organization. The summary was produced for a first consultation with the faith community since Alma Ata (1978), marked the $20^{\text {th }}$ anniversary of the Declaration, and noted the changes in faith-based interactions with 
WHO and updating of primary healthcare. WHO had begun a Primary Healthcare initiative in late 2006. Reinvigorating primary healthcare and strategic partnerships for health in light of the relative success of the " 3 by 5 " effort became a priority, and while the 2008 World Health Report on Primary Healthcare said virtually nothing about the role of faith-based organizations and the history of the primary healthcare initiative since 1968, it curiously validated the results sought by the WCC in 1978. The WHO report called for decentralization and communitydeveloped services and responses to health crises. Three decades of government-managed PHC had produced mixed results at best and only represented a portion of the Primary Healthcare revolution, which had continued unabated in the faith communities since the 1960s. The introduction to this WHO Report contains these words:

The report notes the revival of the primary healthcare and health systems debate with WHO. This report also emphasized that if WHO wants to encourage this framework as a more sustainable system of health servicing and delivery, including FBS, although not always easy, is necessary to achieving desired coverage. As the WHO documentation shows, FBOs cover about 40 percent of the healthcare and services in Africa alone. But they tend to operate outside governmental planning exercises and are, therefore, generally unrecognized. This has significant implications for how new initiatives are-such as the International Health Partnerships and others, as well as funding mechanism design, plan and deliver national health programs. Varied assets used by FBOs physical, human and community support have great potential for increased value to the benefit of their communities and nations. The report details how engaging with FBOs will bring challenges, but the authors conclude that all parties stand to gain by this approach. Ultimately the communities that both WHO and FBOs seek to serve will be better cared for, and the possibility of achieving the MDGs will be enhanced. ${ }^{6}$

Other studies commissioned in the same years also demonstrated the inherent inequities of financial support for faith-based, targeted NGO programming and services from multi-laterals such as UNAIDS, Global Fund, European Union, UNAIDS and WHO. Yet service provision by faith-based health services or religious health assets could be evaluated and accounted for if only these entities were asked for their data. Data was kept, details were measured, and quality controls enumerated and accounted. In many ways, the RHAs were competing with profit and non-profit organizations alike, through local chapters of transnational organizations like Lutheran World Service, Tearfund, Christian Aid, Catholic Relief, CARITAS Internationalis, Anglican Health Network, Adventists Development and Relief Association (ADRA), Office Health Ministries-Seventh Day Adventist Church, and specific consortia or associations, like Christian Health Associations. All of this was happening at the country level.

\section{MDG's and Foundational Partner- ships}

With these results and the urgency of international health issues pressing on the leadership of the United Nations and the drive to meet the Millennium Development Goals (MDGs), many of the UN agencies and specialized programs began reaching out to faith-based organizations and religious communities in an effort to enroll communities and nations in the MDG process. Among the global leaders who reached out was Dr. Thoraya Obaid, a Muslim from Saudi Arabia, who was appointed Director of UNFPA. She announced in the first meeting with UNFPA Board that she would reach out to faith communities who both supported and challenged the aims of objectives of the population agency. She pointed to the Board and to leaders in the UN system that she needed all players at the table. In that spirit, they came. In 2008, UNFPA 
established the Global Interfaith Network on Population and Development, representing an agreement of faith communities around the world on principles of working together and with UNFPA to combat global challenges of maternal death, AIDS and poverty, violence against women, and issues related to youth and migration. Again, with her leadership at the center, in 2009, Dr. Obaid invited all the UN agencies to collaborate and promote discussion across the UN agencies on the role of faith groups through a UN Inter-Agency Taskforce on Engaging FBOs in Development that she established. More importantly, all the UN programs and UN specialized agencies and institutions sent representatives to the meeting, demonstrating again that there was global activity among and interest in such entities.

Through these activities, a variety of studies were launched and completed by 2010 . Each of them pointed to a paucity of measurable verifiable data and a dearth of anecdotal information. UN Administrators keep calling for scientific or empirical data to establish a solid and reliable foundation for government engagement with religious entities at country level. That said, the real evidence is that RHAs are there and actively engaged already. While it is still painfully true that they do not appear on WHO Health Maps (previously discussed), the work continues, nonetheless, and agreements are being made in a non-systematic way. Perhaps the more important information is what is going on since 2010, with whom, why, and how?

\section{Summary}

Thus, this "revolutionary" movement of service provision or resource sharing between governments, NGOs, and, now, faith-based organizations is not new. While it is evident that there have been moments of great flourishing and expansion of international health work with faith-based organizations, there have also been times of neglect, disinterest, and even distrust. However, relationships between multilaterals and UN agencies and programs have often been brokered by the World Council of Churches and the
Christian Medical Commission, since the late 1960s. The moment is right, though, for ongoing engagement and expansion of collaborative work with faith-based or faith-inspired organizations. It is already underway, built on a foundation of hundreds of years of Christian Mission work as well as a recent, careful, and more researched international readiness.

With or without studies, it is still patently clear that Religious Health Assets (RHAs) are still providing healthcare services to communities and persons in need. The fact remains that in WHO-generated health service area maps, governments still tend to ignore most activities by faith-based organizations, with the notable exception of the Christian Health Association of Kenya (CHAK) that is identified as part of the Nation Health Plan of Kenya. This makes CHAK accountable for delivery of certain health services to meet certain national goals and objectives. The fact remains that the mission and purpose of government and of faith communities is still a variance and should be. Nonetheless, there remains a common purpose caring for those in need. The original nine points identified in the mid-1960s are still a viable agenda for considering health services provision by faith communities. These include the following: comprehensive health care, community organization, cooperation with governments and other agencies, interchurch coordination and cooperation, planning mechanisms appropriately structured in regional and local organizations, re-orientation of personnel, need for administrative reorganization, data systems, and facing the problems of population dynamics. ${ }^{1}$

Finally, as a postscript, the notion of "prophetic" ministry (which holds in tension the demands for justice and enactment of mercy in our own time) and the larger concerns of justicemaking as part of the reason for providing health services and health care need to be debated, yet again, to ensure that the charism (calling) to health and healing are held in tandem. 


\section{References}

1. Grundmann CH. Sent to heal! University Press of America, Inc. Boulder: 2005. [p.1, 8]

2. Smith D, editor. A Christian medical commission [Contact no.161/162] June. Geneva: 1998. Available from: https://www.oikoumene.org/en/what-wedo/health-and-healing/con161162_p218.pdf [last accessed on 8 April 2014] [p. 2,16, 8-10.]

3. World Health Organization. WHOQOL and Spirituality, Religiousness and Personal Belief (SRPB), a report from WHO/MSA/MHP/ 98.2.Geneva: 1998 [p. 3,4,6] Available from:

http://www.scielosp.org/scielo.php?pid=S00349102003000400009\&script=sci arttext\&tlng=en

4. African Religious Health Assets Program. Appreciating Assets: The Contribution of Religion to Universal Access in Africa: Mapping, Understanding, Trans- lating and Engaging Religious Health Assets in Zambia and Lesotho In support of Universal Access to HIV/AIDS Treatment, Care and Prevention. Geneva: 2006. Available from:

http://www.arhap.uct.ac.za/pub_WHO2006.php [last accessed 9 April 2014].

5. World Health Organization. Executive Summary: WHO-CIFA Consultation on NGO Mapping Standards Describing Religious Health Assets, March 2010, World Health Organization and Center for Interfaith Action on Global Poverty. Geneva: 2010. [p.3] Available from:

http://www.anglicanhealth.org/ResourcesPage.aspx [last accessed on 9 April 2014].

6. Karpf T, Ross A, editors. Introduction: Building from a Common Foundation: The World Health Organization and Faith-based Organizations in Primary Health Care. Geneva: World Health Organization, December 2008. [p.4, 8]

This article is Peer Reviewed

Competing Interests: None declared.

Correspondence: The Reverend Canon Ted Karpf, Post Office Box 6654 Santa Fe, NM 87502-6654, USA ted.karpf@gmail.com

Cite this article as: Karpf T. Faith and health: past and present of relations between faith communities and the World Health Organization. Christian Journal for Global Health (August 2014), 1(1): 16-25.

(C) Karpf, T This is an open-access article distributed under the terms of the Creative Commons Attribution License, which permits unrestricted use, distribution, and reproduction in any medium, provided the original author and source are properly cited. To view a copy of the license, visit http://creativecommons.org/licenses/by/4.0/

www.cjgh.org

June 2014. Christian Journal for Global Health, 1(1):16-25. 